\title{
Study on Profiting Model of Auto Finance Companies-Taking SAIC-GMAC as an Example
}

\author{
Chaoxin Ji \\ College of Economics and Management, Hubei University of Automotive Technology, Shiyan, Hubei, \\ 442002
}

Keywords: Auto finance, SAIC-GMAC, Profiting model of auto finance companies.

\begin{abstract}
By analyzing the reasons for SAIC-GMAC to securitize its car loans, as well as its process, performance and problems caused, this paper studies the new profiting model of this auto finance company, so as to identify new idea for profiting model of auto finance companies in China and strengthen the role of automotive industry in facilitating the national economy of China.
\end{abstract}

\section{Introduction}

Since China released the Measures for the Administration of Finance Companies on October 3, 2003, twenty-five specialized auto finance companies have been established upon the approval of the China Banking Regulatory Commission. In China, the percentage of car loans was $17 \%$ in 2015, but slightly decreased. However, the average percentage in developed countries is $70 \%$, even $65 \%$ in India. At present, the overall penetration rate of auto finance industry is less than $30 \%$ in China, which is much lower than that in Europe, U.S. and other developed countries. Now, auto finance companies raise funds mainly through bank loan. Hence, the development of auto finance is affected by such factors as incomplete credit system and low repayment capability of auto finance companies; insufficient legal system and social guarantee, and centralized credit loan risks; high threshold for loan, complicated formalities and single product available, etc.

Founded in August 2004, SAIC-GMAC is China's first auto finance company established upon the approval of the China Banking Regulatory Commission. Now, the company has a registered capital of 3.5 million RMB contributed by SAIC Finance, GMAC UK PLC and Shanghai GM Automotive Company Limited, which hold $45 \%, 35 \%$ and $20 \%$ of its shares respectively. By the end of 2016, the company had the total assets exceeding 84 billion RMB, and offered the all-directional auto finance services for more than $3,180,000$ car buyers through the cooperation with more than 7,000 car dealers in more than 360 cities of China, making it the leader of auto finance industry in China. This paper will study the company and explores its innovation in the profiting model of auto finance.

\section{Reasons for SAIC-GMAC's Asset-backed Securitization of Credit Loans}

As stipulated in the Measures for the Administration of Auto Finance Companies, an auto finance company shall not set up a branch in any place other than its registered place. However, it does not forbid auto finance companies from engaging in businesses in any other place. Taking advantage of this ambiguity in policy, SAIC-GMAC sends a great number of sales representative to many places outside Shanghai, and cooperates with GM car dealers in those places for car loan business.

This model has such advantages as close cooperation with dealers, strong ability of risk control, low percentage of bad debts and even zero bad debt. However, it leads to very slow expansion and makes it difficult to obtain the market share rapidly. Additionally, GMAC's fund sources are restricted to some extent. Compared with free finance for auto finance companies in the principle of interest maximization in other countries, the China Banking Regulatory Commission allows only three channels for finance, i.e. using the capital share of the company, absorbing the deposits of domestic shareholders for more than 3 months, and borrowing from finance institutions. As the financial problem cannot be solved by receiving the deposits from shareholders, and it is very 
difficult to borrow from the competing finance institutions, the company has to make an innovation in the profiting model, i.e. asset-backed securitization of car loans.

\section{SAIC-GMAC's Asset-backed Securitization Process of Credit Loans}

In February 2016, SAIC-GMAC issued the "Rongteng 2016 First Trust for Asset-backed Securitization of Personal Car Mortgage Loans", which is a product of asset-backed securitization for auto finance company. The basic process flow is shown in Fig. 1 (with solid line standing for legal relations between parties and broken line for cash flow).

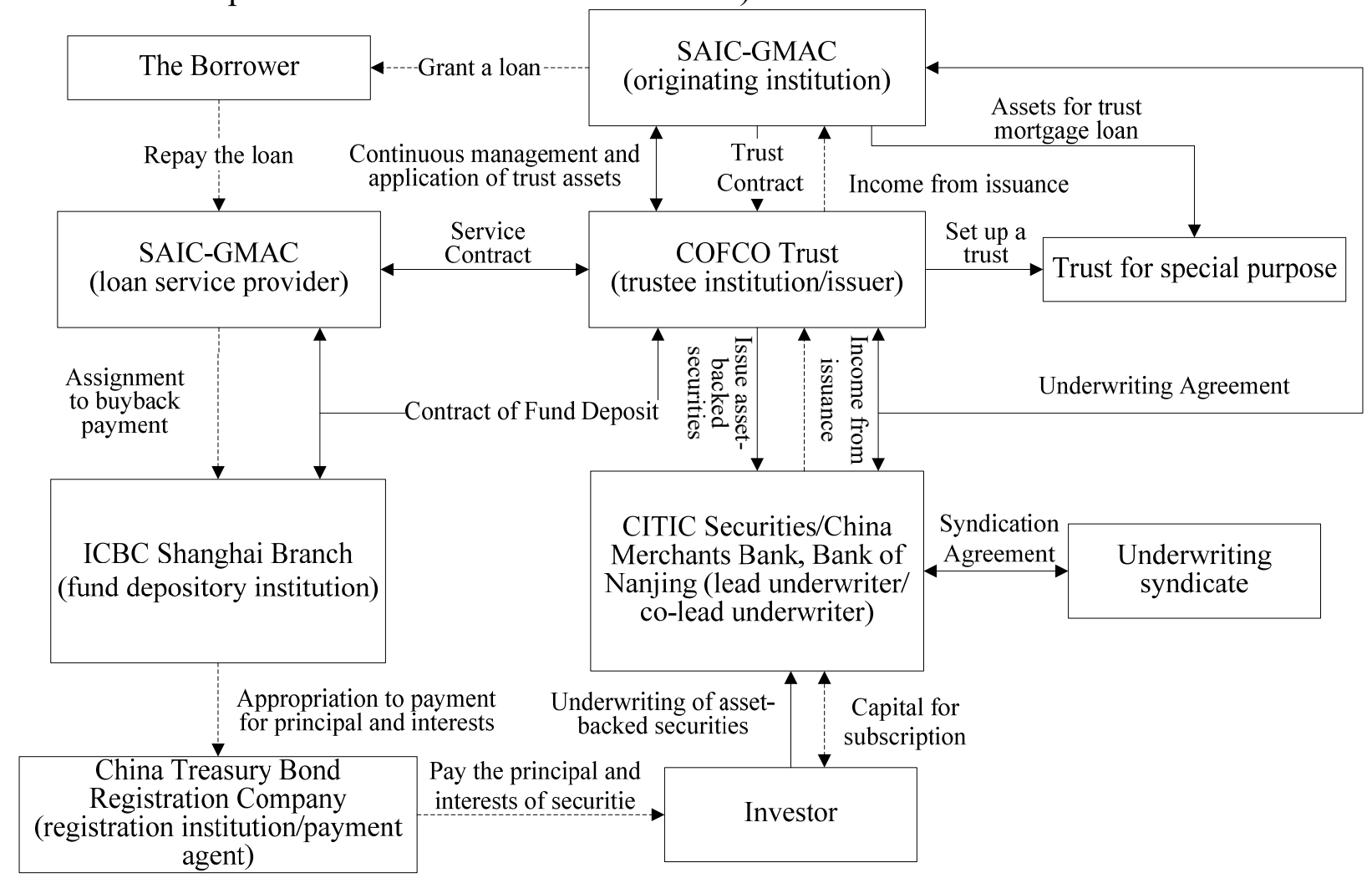

Fig. 1 Issuing Process of Rongteng 2016 First Trust for Asset-backed Securitization of Personal Car Mortgage Loans

As revealed in the above figure, asset-backed securitization mainly involves:

Originating institution-SAIC-GMAC;

Trustee institution-COFCO Trust Co., Ltd.;

Lead underwriter-CITIC Securities Co., Ltd.;

Co-lead underwriter-China Merchants Bank Co., Ltd. and Bank of Nanjing Co., Ltd.;

Fund depository institution-Industrial and Commercial Bank of China Co., Ltd. Shanghai Branch;

Rating institution - China Bond Rating Co., Ltd. and China Lianhe Credit Rating Co., Ltd.

First, SAIC-GMAC selects 2,999,999,999.89RMB from the accounts receivable from debtors based on the recommendations of CITIC Securities Co., Ltd., China Merchants Bank Co., Ltd. and Bank of Nanjing Co., Ltd., and puts it into the pool. Then, it transfers the fund through "true sale" to COFCO Trust according to the Trust Contract, but the fund is actually deposited with ICBC Shanghai Branch according to the Contract of Fund Deposit.

Then, the securities with the initial fund of 3 billion RMB are divided into Preferred A-1 and A-2 asset-backed securities and secondary asset-backed securities. Among them, Preferred A-1 securities have the fixed coupon rate, A-1 securities have floating interest rate, and there is no coupon rate for secondary securities. Before the earnings of A-1 and A-2 are entirely realized, secondary asset-backed securities will not receive any distribution of trust earnings. 
On this basis, the asset pool at the initial assessment by China Bond Rating has the weighted average account age of 11.44 months, which is moderate. The weighted average remaining period is 24.28 months. The initial asset pool involves a great number of debtors and a lot of loans. The loans added to the pool are highly scattered, so there is very low level of centralization risks and a moderate risk exposure period on the whole. Based on the distribution of borrowers in the initial asset pool, the age ranges from 20 to 40 years old, and their professions are well paid. The weighted average debt-to-income ratio is 3.73 times, which provides the satisfying guarantee for repayment. After comprehensively considering the results from key element stress test and cash flow stress test of underlying assets, it is believed that preferred asset-backed securities can obtain the credit rating of AAA.

\section{Analysis on SAIC-GMAC's Asset-backed Securitization of Credit Loans}

Through asset-backed securitization, SAIC-GMAC has made the following achievements:

(1) Securities are issued with the combination of fixed interest rate and floating interest rate to greatly reduce the influence of interest rate on bonds.

(2) By adopting the transaction pattern of continuous purchase and imposing an early amortization period to speed up the trigger value of liquidation and default events, the uncertainness of credit quality of underlying assets caused by the structure of continuous purchase is alleviated to some extent.

(3) Thanks to the strict standards for adding assets to the pool, the borrowers in the initial asset pool have an average age of 33.11, a stable income and strong will to repay. For very low centralization level of borrowers in the initial asset pool, the balance of loans owned by top 10 borrowers takes up $0.08 \%$ of the total amount, which is $0.15 \%$ for top 20 borrowers. This decentralization of borrowers can reduce the default risk caused by personal default effectively.

(4) The number of institutions involved is increased. This financial bond is publicly issued by co-lead underwriter CITIC Securities and Bank of China through centralized placement with registration and record among all banks in the nationwide market.

(5) Bank of China Shanghai Branch provides the unconditioned irrevocable joint and several liability guarantee for the total amount of this bond. The credit rating is AAA.

However, this model also makes the company face some issues as follows:

(1) The registration for transfer and change of mortgage rights is not handled for the securities, making it highly risky. Compared with Tongyuan securitization of personal car mortgage loans in 2012 and 2014, which did not entirely abandon the control over the loans, this transaction of Rongteng asset-backed securitization keeps all risks and remunerations, which can increase the rate of return in finance, but clearly increase the risk level.

(2) The influence of macro economy on the quality of credit loans is not overlooked. The assessment report takes into account the regional distribution, income distribution and repayment capability of borrowers, but overlooks the fact that industrial production has slowed down together with the continuous decrease of economic growth rate in China ever since 2015. Clearly, this situation may affect the unemployment rate of borrowers and the stability of their income, causing further influence on the quality of credit loans.

(3) The pattern of continuous purchase is uncertain. Rongteng asset-backed securitization employs the transaction results of continuous purchase, but the management capability and will of trustee institution may be uncertain in the continuous and dynamic process. Meanwhile, if the company fails to provide sufficient and qualified assets for sale to the trust during the period of continuous purchase, the fund of the trust will be left unused for a long time, which further affects the earnings of underlying assets.

(4) The collaterals for loans come from SAIC-GMAC, so they have some risks. If cars are recalled for quality problem, it will lead to adverse effect.

(5) Some data used in the analysis of asset pool may be not accurate, e.g. default rate of car mortgage loan, and early repayment rate, etc., which will increase the uncertainness of analysis. 


\section{Enlightenment from SAIC-GMAC's Asset-backed Securitization of Credit Loans}

\subsection{Selecting the suitable assets for securitization}

First of all, suitable assets should be selected for restructuring and pooling. For instance, SAIC-GMAC classifies the suitable assets in terms of loan distribution, borrower distribution, and collateral distribution. Among them, the loan distribution is further divided into eleven situations, e.g. classification in terms of "mortgage loan" contract term and classification in terms of "mortgage loan" account age. Compared with the combination of accounts receivable with shorter account age, the combination of accounts receivable with longer account age has more stable performance, since the accounts receivable with higher risk level are removed from the combination as the time goes by. In the end, only more stable accounts receivable will be kept.

Second, the geographical distribution of borrowers is also taken into account. If the centralization level is too high, the cyclic change of regional economy will affect the asset pool dramatically. If the centralization level is low, the risk level of regional centralization will be reduced. [1]

\subsection{Selecting the suitable methods for credit enhancement}

In the internal credit enhancement for the first Rongteng asset-backed securitization in 2016, the hierarchical structure is designed to contain "A1 Asset-backed Securities", "A2 Asset-backed Securities" and "Secondary Asset-backed Securities". The main information is presented in Table 1:

Table 1 Rongteng First Asset-backed Securities of Personal Car Mortgage Loans in 2016

\begin{tabular}{|c|c|c|c|}
\hline Item & $\begin{array}{c}\text { A1 Asset-backed } \\
\text { Securities }\end{array}$ & $\begin{array}{c}\text { A2 Asset-backed } \\
\text { Securities }\end{array}$ & $\begin{array}{c}\text { Secondary Asset-backed } \\
\text { Securities }\end{array}$ \\
\hline Scale (RMB) & $200,000,000.00$ & $2,510,000,000.00$ & $289,999,999.89$ \\
\hline $\begin{array}{c}\text { Percentage in Total } \\
\text { Asset-backed Securities (\%) }\end{array}$ & $6.67 \%$ & $83.67 \%$ & $9.67 \%$ \\
\hline Coupon Rate & Fixed interest rate & $\begin{array}{c}\text { Benchmark interest rate } \\
\text { +Basic interest rate }\end{array}$ & - \\
\hline Rating & AAA & AAA & - \\
\hline
\end{tabular}

(Note: The data in this table are sourced from Reference [2] Website of Shanghai GM Automotive Company Limited: http://www.gmacsaic.net)

As shown in Table 1, "A1 Asset-backed Securities", "A2 Asset-backed Securities" and "Secondary Asset-backed Securities" take up 6.67\%, 83.69\% and 9.67\% of total securities respectively in this "asset-backed securitization". Preferred asset-backed securities represent the "priority to earnings", while secondary asset-backed securities have "secondary right to earnings". In each payment, the principal and earnings of A2 must be paid after A1, so they provide the credit support for A1. Meanwhile, preferred asset-backed securities enjoy the payment of principal and earnings prior to secondary asset-backed securities, so secondary asset-backed securities provide the support for preferred asset-backed securities. In this way, credit enhancement is realized.

Excess spread refers to the interest income remaining after the interests on car loans are deducted by the interests on securities issued in the securitization and the service fees for the securitization. Since its fund cost is higher than the cost of bank loan, SAIC-GMAC requires that the interest rate of car loans must be higher than the interest rate of the bank loans of the same term. In this asset-backed securitization, the weighted average interest rate of underlying assets is $12.97 \%$, so there is much excess spread between rate of return on asset pool and securities and taxes, which provide further credit support for the investors of preferred asset-backed securities.

Meanwhile, three reserve accounts are created in this transaction to reinforce the protection for paying the principal and earnings of "asset-backed securities", i.e. trust liquidity reserve account, trust combination and offset reserve account, and trust service transfer and notification reserve fund. Moreover, SAIC-GMAC makes special arrangement for the repayment structure, which will trigger some mechanism to deal with any default event if it occurs. [3]

\subsection{Enlightening the development of auto finance companies in China}

In China, auto finance companies may smoothly implement the securitization under the guidance of industrial policies and after the optimized allocation structure and strategic cooperation are formed among auto manufacture industry, auto finance industry, banking industry, trust institutions and 
securities institutions. Hence, a national credit information platform must be established to form a state-level credit network, in order to facilitate the development of auto finance and satisfy the increasing needs for auto finance. [4]

Additionally, auto finance industry must persist in the market-oriented insurance reform. The development quality and effectiveness of auto finance market will be effectively guaranteed by continuously enhancing the development quality and effectiveness of insurance market.

Eventually, it is necessary to strengthen the risk management of auto finance market. China may borrow the risk management methods from developed countries, e.g. developing new types of mortgage loan to avoid interest rate risk; using financial derivative instruments to avoid the risk caused by fluctuation of interest rate; selling the loans in the secondary market; and dealing with bad debts in an efficient and timely manner to reduce losses, etc.

\section{Conclusion}

As revealed in the Analysis on the Annual Reports of Some Listed Automobile Dealer Groups released by China Automobile Dealers Association, the listed dealer groups' average gross profit margin for sale of new vehicles was $3.26 \%$ within the report period, down $0.55 \%$ compared to the same period of the previous year. In recent years, these listed automobile dealer groups have engaged in the auto finance businesses including car insurance and insurance extension, which become reliable profit sources and new profit growth points for them. In 2015, these 12 automobile dealer groups in the statistical scope realized the income of 6 billion RMB from auto finance business, up $3.31 \%$ on a year-on-year basis. During the transverse and longitudinal expansion, penetration and extension of auto finance in the automobile industry, the financial capitalization must be gradually promoted in the whole automobile industry. Auto finance is not only a major profiting sector of automobile industry, but also a new way for development of finance industry through its "blending" operation with such a public commodity of high price, high complexity and high added value.

\section{Acknowledgement}

This work was financially supported by Hubei Provincial Department of Education, Research on Auto Finance System for Commercial Vehicles-Based on Dongfeng Commercial Vehicle Company Limited (13q086); the scientific research fund for young scholars of the University, Research on Auto Finance System for Commercial Vehicles (2012XQ03).

\section{References}

[1] Hongli Niu, Jun Wang. Power-law scaling behavior analysis of financial time series model by voter interacting dynamic system. Journal of Applied Statistics, 2013, 40(10):14-15.

[2] Website of Shanghai GM Automotive Company Limited: http://www.gmacsaic.net/.

[3] Amol Ambardekar, Mircea Nicolescu, George Bebis et al. Vehicle classification framework: a comparative study. EURASIP Journal on Image and Video Processing. 2014.1:1-13.

[4] Jihong Lin. A study on development of auto finance companies in China. Foreign Investment in China. 2013.1(11):19-20.

[5] Chenyu He, Fang Gu. Auto Finance Service. China Machine Press. 2006.04: 34-39. 